\title{
3 \\ Gezellig: A Dutch cultural keyword unpacked
}

\author{
Bert Peeters
}

\section{Introduction ${ }^{1}$}

The term keyword (or key word), used with or without the adjective cultural (which is always understood to be there), has been a staple of Natural Semantic Metalanguage (NSM) semantics for the last 20-odd years; it figures prominently in the title of Wierzbicka's trailblazing book Understanding Cultures through their Key Words (1997), and in that of Levisen and Waters' collective volume Cultural Keywords in Discourse (2017). Cultural keywords are 'highly salient and deeply cultureladen words' (Goddard and Wierzbicka 1995: 57) or, in a more recent definition, 'culture-rich and translation-resistant words that occupy focal points in cultural ways of thinking, acting, feeling, and speaking' (Goddard 2017: 9; see also Goddard 2015: 386). Cultural keywords exist in all languages but are rarely studied in a way that combines total transparency (for cultural insiders and outsiders alike) with the absence of any cultural bias. Transparency and bias avoidance can only be achieved with a sophisticated methodology such as the NSM approach, which relies on decades of empirical research into the true universals of meaning.

1 This chapter is dedicated to a mentor, colleague and friend I can't thank enough for all she has meant and continues to mean to me. This is for you, Anna. Enjoy! The text has undergone a substantial rewrite, especially after the first peer review. I am grateful for all feedback received and am solely responsible for any inaccuracies remaining. 
Among the North and West Germanic languages, Dutch is, to the best of my knowledge, together with Faroese, the only one never to have been subjected to properly informed NSM analysis. The table of Dutch exponents of NSM primes in Appendix 3.1 is new: no such table has ever appeared in print. One Dutch cultural keyword that has been occasionally mentioned in the NSM literature is the adjective/adverb gezellig. Section 2 of this chapter provides some initial information on this elusive concept. Section 3 unpacks it in an intuitively intelligible and universally accessible way using NSM primes and syntax. Dutch versions of the various explications may be found in Appendix 3.2. Importantly, explications are experiments; none of them are final. Wierzbicka (1992: 551) and Levisen and Waters (2017: 241) have described explications as 'hypotheses'. The explications in this chapter are no exception.

\section{Gezellig, a cultural keyword}

The meaning of gezellig is anything but straightforward, as American philosophy professor Hilde Lindemann found out shortly after arriving from the USA on a European study trip:

Over dinner on my first night in the Netherlands, my hosts nodded when I told them how much I liked the restaurant. 'Ja,' they said, 'it's gezellig, isn't it?' Aha, thought I, my first lesson in Dutch.

'What's gezellig?' I asked.

'It means—well, sociable,' Enne explained.

'But not exactly,' Menno added. 'More like cozy.'

'Sort of like the German gemütlich?'

'No, not really,' said Marian. 'A place could be gemütlich even when you're the only person in it, but it wouldn't be gezellig.' The others agreed. Gezellig didn't go with solitude. (Lindemann 2009: 40)

Or does it? Housing ads referring to gezellige éénpersoonskamers 'gezellig single rooms' are not semantically incoherent, and yet such rooms are not meant to be occupied by more than a single occupant, who will spend most of his/her time in them alone. Likewise, people who prefer to spend an evening gezellig alleen 'gezellig alone' at home do make sense. Phrases such as gezellige éénpersoonskamer and gezellig alleen demonstrate that, in contemporary Dutch, the adjective gezellig has meanings it didn't have 
in centuries past. Etymologically, gezellig is related to gezel, a noun that has had several meanings over time, all implying membership of a team or a group, and that now means 'companion' or 'mate'. Another noun that derives from gezel is gezelschap 'company' (as in the phrase 'be in good company'). Nowadays, the link between gezellig and gezelschap is more keenly felt than that between gezellig and gezel, which in its everyday use has lost some currency (except in compounds such as levensgezel 'life companion' and vrijgezel 'bachelor [unmarried male]'). However, neither link is strong enough to make phrases such as gezellige éénpersoonskamer and gezellig alleen ungrammatical.

According to van Baalen (2003: 16), references to the 'untranslatability' of the word gezellig have become so much of a cliché that nobody goes to the trouble anymore of putting the claim to the test. The same author goes on to say that other languages don't appear to have a word that covers its entire range of use-but this, she adds, holds true for many words in many languages. One source describes gezellig as covering 'everything from cozy to friendly, from comfortable to relaxing, and from enjoyable to gregarious'. 'The noun gezelligheid 'gezellig-ness', on the other hand, derived from the adjective by adding the suffix -heid, 'may be variously translated as sociability, conviviality, companionableness or snugness and cosiness' (Pradhan 1990: 56). Instead of bringing clarity, statements such as these tend to muddy the waters; they may explain why a common strategy to clarify the meaning of the keyword gezellig involves exemplification, as illustrated in the same passage, which includes references to:

een gezellige man (a sociable man), een gezellig glaasje (a cheerful or sociable glass of wine or beer), een gezelIige avond (pleasant evening), een gezellig avondje (social evening), een gezellig hoekje of café (a cozy corner or cafe), gezellig weer (pleasant weather), etc. (Pradhan 1990: 56)

In his 99 Tips for Dealing with the Dutch, cross-cultural trainer Hans Kaldenbach comes up with a list of his own:

Drinking coffee can be gezellig. Visiting a friend can be gezellig. So can an open fire. A neighborhood can have a gezellig feel to it; a painting depicting a rustic setting can also be gezellig. If someone refers to you as gezellig, take this as a compliment. (Kaldenbach 1995: 22)

2 Available at: www.dutchamsterdam.nl/155-gezellig (published 20 April, 2007). 
Goddard (2017: 9) mentions gezellig, which he glosses as 'convivial, cosy, fun', as a prime example of a cultural keyword that has 'rise[n] to the attention of a speech community and attain[ed] an iconic and often contested status', something many other keywords don't. ${ }^{3}$ The iconic status of gezellig is beyond dispute: it is recognised at all levels of society (for some impressions, see Dronkers 2013: 99) and it was further enhanced by former US president Barack Obama at the end of his 2014 visit to the Netherlands, when he addressed a packed press conference in the following terms: 'I'm told there's a Dutch word that captures the spirit, which doesn't translate exactly in English, but let me say that my first visit to the Netherlands has been truly gezellig. ${ }^{4}$ Its status as a cultural keyword and an indicator of a cultural value (gezelligheid 'gezellig-ness') ${ }^{5}$ has often been noted (see e.g. Gaston Durnez quoted in Driessen 1997: 49-50; van Baalen 2003: 16, 19; Lindemann 2009: 40; Goddard 2017: 9), even though there are dissenting voices-which is normal in debates about cultural values. As it turns out, the word gezellig is more (perhaps even much more) salient north of the border. Native speakers of Belgian Dutch (e.g. the Belgian writer Gaston Durnez, quoted in Driessen 1997: 49-50) have been known to single out gezelligheid as something that typifies speakers of Netherlands Dutch much more than it does them. The internet corpus on which this chapter is based provides spectacular proof of this point: most of the examples it includes come from domain names ending in.$n l$ or contain other indications that give them away as belonging to Netherlands Dutch. Even so, I would like to argue that gezellig is a cultural keyword of Belgian Dutch as well. There may be some minute differences in meaning, and Flemish people may not use the word as much, but they still attach a lot of importance to gezelligheid. ${ }^{6}$

3 Goddard (2015: 386) is a little more precise: he opposes keywords that 'rise to the attention of a speech community (usually by way of contrast with outsiders) and attain an iconic, and therefore frequently contested status, in national identity discourses' to those that for most speakers 'stay below the horizon of consciousness'.

4 Available at: www.youtube.com/watch?v=rSClTFZ6xa8 (uploaded 25 March 2014).

5 Cultural keywords are by definition indicators of cultural values (Levisen and Waters 2017: 6, 240).

6 A separate paper and a more targeted corpus of Flemish or Belgian Dutch data would be needed to prolong the current investigation and reach a more definitive view. 


\section{Gezellig unpacked}

To get a better feel for the meaning(s) of the Dutch cultural keyword gezellig, I had a closer look at the first 250 occurrences of the corresponding lemma identified in a Sketch Engine (www.sketchengine.eu/) search carried out on 11 September 2018. ${ }^{7}$ The sheer number of place-oriented examples in the sample suggests that gezellig is first and foremost a quality attributed to places. Other examples show that periods of time, activities, events and features of a place, such as its atmosphere and bustle, are often called gezellig as well. Humans and other living beings like animals and plants can be gezellig, too, and so can inanimate objects. To account for this variety of uses, several NSM explications are required. The most important are presented in the subsections that follow. ${ }^{8}$

\subsection{Gezellig $+\mathbf{N}_{\mathrm{P} L A C E}$}

Just over half of gezellig $+\mathrm{N}$ combinations in the Sketch Engine sample refer to a place (an individual room, the family home, an eatery, an openair market, an entire village or town, a hotel, etc.). A few examples are reproduced in (1) to (3).

(1) Kortom, 'Huize Pruimtabak' is hét meest gezellige bejaardentehuis van het land.

'In short, "Huize Pruimtabak" is the most gezellig retirement home in the country.'

(2) Wie kan me een gezellige kroeg aanbevelen waar het Nederlands volk in New York onze jongens kan aanmoedigen?

'Who can recommend a gezellig pub where Dutch people in New York can cheer on our boys?'

7 My thanks go to Patrick Dendale (Universiteit Antwerpen), who executed the search for me.

8 The use of gezellig with animals (een gezellige poes 'a gezellig cat'), plants (een gezellige anemoon 'a gezellig anemone') and inanimate objects (een gezellige borrel 'a gezellig snifter') had to be left out due to limitations of space. Search results were occasionally complemented with hits returned by more targeted Google searches and identified by means of a bracketed $(G)$. 
(3) Het gezellige en kleinschalige complex bestaat uit 3 appartementen en 3 studio's.

'The gezellig and small-scale complex comprises 3 flats and 3 studios.'

Use of the adjective gezellig often goes hand in hand with diminutive suffixation on the place name, as in (4) to (6):

(4) Mocht u echter wel een keer uit eten willen in één van de vele gezellige restaurantjes die Harderwijk rijk is, dan zijn onze medewerkers u vanzelfsprekend graag van dienst.

'If ever you fancied dining out for once in one of the many gezellige restaurants $_{\text {DIM }}$ Harderwijk is rich in, our team members will obviously be happy to be of service.'

(5) Wat te denken van Alassio, dat vele oude kerken, groene parken met palmbomen, kleurrijke planten en gezellige pleintjes herbergt.

'What to think of Alassio, which has plenty of old churches, green parks with palm trees, colourful plants and gezellig squares ${ }_{\text {DIM.' }}$ '

(6) De kustlijn is maar liefst $960 \mathrm{~km}$ lang en er zijn heel wat gezellige vakantieplaatsjes met hotels van uitstekende kwaliteit.

'The coast line is a whopping $960 \mathrm{~km}$ long and there are plenty of gezellig holiday spots ${ }_{\text {DIM }}$ with hotels of outstanding quality.'

Impersonal constructions relying on an indefinite pronoun (het 'it') and a copular verb (e.g. zijn 'to be') are common as well. They involve a place name embedded in a prepositional phrase, as in (7), or a locational adverb (bier 'here', daar 'there', er 'there [unstressed]') recalling a place that was mentioned before, as in (8), where daar refers to the stands, and (9), where er refers to a previously described English town:

(7) In Pipodorp is het altijd gezellig.

'In Pipodorp it is always gezellig.'

(8) Gelukkig was de tribune groot genoeg om de ruim 750 supporters te herbergen en was het daar best gezellig.

'Fortunately the stands were big enough to host the 750-odd supporters and it was really gezellig there.' 
(9) Het is een typisch Engels plaatsje met een groot marktplein in het midden waaraan meerdere pubs, hotels en vakwerkhuisjes zijn gevestigd. Het lijkt er altijd gezellig te zijn.

'It is a typical English town with a big market place in the centre where several pubs, hotels and workshops are located. It always looks gezellig there.'

For a place to qualify as gezellig, several conditions must be met. Most crucially, there must be at least a potential for the presence of humans. A place where no humans ever dwell can't be called gezellig. A gezellig place is one that makes people feel good, even when they are not in it and nobody else is in it either. People can see themselves spending time in such a place, alone or (space permitting) together with others. They can see themselves doing things in it, once again alone or with others. In the case of bigger places that allow for a larger human presence, gezellig implies at least the possibility, and often the reality, of collective enjoyment. There is a perception that nothing can go wrong.

Summarising the above in NSM terms, a gezellig place may be described as in $[\mathrm{A}]$ :

\section{[A] een gezellige plaats 'a gezellig place'}
a. a place
b. when people think about this place, they feel something good
c. they want to be in this place
d. they want to do some things in this place
e. when people are in this place, they can feel something good
f. bad things can't happen to people in this place

As an attribute of places, gezelligheid has often been compared to the Danish concept of hygge, subjected to detailed NSM analysis in Levisen (2012: 80-114). To describe a place where there is hygge, the adjective hyggelig is used. Both are no doubt cultural keywords, but the noun is the base form. It is the other way around in Dutch, where gezellig (the adjective) is the base form, and the noun gezelligheid is derived (and much less commonly used). 


\subsection{Gezellig + N referring to atmosphere}

Uses of gezellig that relate to atmosphere or ambience can be viewed as extensions of uses related to place. There can be no atmosphere, in the relevant meaning, unless there is a place where that atmosphere 'reigns'. A semantically similar verb, heersen, is used in Dutch; I will rely on it in the header of the NSM explication below. The place itself may be explicitly mentioned, as in (10) and (11):

(10) Onze polyvalente, sierlijke tenten in combinatie met hun verfijnde inrichting zorgen steeds voor een gezellige sfeer waarin uw feest van succes is verzekerd!

'Our versatile and graceful marquees, combined with their refined equipment, always provide a gezellig atmosphere in which the success of your party is guaranteed!'

(11) Deze zaal heeft een gezellige uitstraling door de informele sfeer die hier hangt.

'This hall has a gezellig vibe thanks to the informal atmosphere that reigns here.'

However, location is often implicit, as in (12) and (13):

(12) En dat allemaal in een gezellige ambiance met een hapje en een drankje.

'And all of that in a gezellig ambience with a snack and a drink.'

(13) Met zijn tweeën een avond heerlijk getafeld in een gezellige, knusse sfeer met goede wijn en heerlijk eten.

'The two of us spent the evening deliciously dining in a gezellig, cosy atmosphere with good wine and delicious food.'

Examples (14) and (15) rely on an indefinite pronoun and a copular verb, as did examples (7) to (9).

(14) De opkomst was groot en het was reuze gezellig.

'The attendance was great and it was mightily gezellig.'

(15) Het was heel gezellig met een menigte mensen met kleedjes en stoeltjes en een podium met koortjes, solisten, bands etc. 
'It was very gezellig, with a crowd of people with rugs ${ }_{\text {DIM }}$ and chairs ${ }_{\text {DIM }}$ and a stage with choirs ${ }_{\text {DIM }}$, soloists, bands etc.'

Examples (13) to (15) show that atmosphere is tied up with human presence. There can be no gezellig atmosphere (or any other kind of atmosphere for that matter) without it. In addition, there is a time factor at work as well. In this respect, atmosphere differs from place, in that a place can be gezellig even when there is no one around for at least a brief period of time. Obviously, though, human presence is not a guarantee for a gezellig atmosphere. Dentists' waiting rooms are often singled out as places that are notoriously ongezellig (the prefix on-turns a word into its opposite). How could it be otherwise, since most people, when they visit dentists, are painfully aware of the discomfort that awaits them and not in the mood to socialise??

Explication [B] sums up these observations in NSM:

\title{
[B] er heerst hier een gezellige sfeer 'there reigns a gezellig atmosphere here'
}

\author{
a. it is like this: \\ b. there are people in this place \\ c. these people want to be in this place \\ d. they feel something good when they are in this place \\ e. they are doing some things when they are in this place \\ f. they want to do these things for some time
}

Related to the use of gezellig with nouns conjuring up an atmosphere are the commonly heard cultural imperatives Hou het gezellig! 'Keep it gezellig' (Driessen 1997: 58) and Maak het gezellig! 'Make it gezellig':

(16) Hou het gezellig, warm en stijlvol in de achtertuin met deze Stahl X Vuurkorf? (G)

'Keep it gezellig, warm and stylish in the backyard with this Stahl X Fire pit!'

9 McNeil and Jomeen (2010), on the other hand, have proposed to use gezellig as a concept for managing labour pain, the idea being that creating a gezellig atmosphere in the birthing place will somehow ease the discomfort of childbirth. 
(17) Dus maak het gezellig, mensen, want het gaat een lang weekend worden. $(\mathrm{G})$

'So make it gezellig, people, because it is going to be a long weekend.'

The corresponding verb phrases het gezellig houden 'to keep it gezellig' and het gezellig maken 'to make it gezellig' are illustrated in (18) and (19):

(18) Burgemeester Berend Hoekstra van Leek doet een dringende oproep aan jong en oud om het met de jaarwisseling gezellig te houden. $(\mathrm{G})^{10}$

'Leek's Lord Mayor Berend Hoekstra makes an urgent call to young and old to keep it gezellig on New Year's Eve.'

(19) De eigenaar zal er alles aan doen om het gezellig te maken.

'The owner will do everything to make it gezellig.'

Het gezellig hebben 'to have it gezellig' is the outcome of het gezellig maken:

(20) Wat zeker is is dat ook zij het gezellig zullen hebben en genieten van muziek en alle andere nieuwe kunstvormen.

'What is certain is that they, too, will have it gezellig and enjoy music and all other new art forms.'

Two more phrases worth singling out are gezellig alleen 'gezellig alone' (cf. section 2) and gezellig samen 'gezellig together'. The former is often met with incomprehension, the latter is related to the phrase gezellig samenzijn:

(21) Ik vier Kerstmis gezellig alleen met een zelfgemaakt driegangenmenu en een lekkere fles cava erbij. (G)

'I celebrate Christmas gezellig alone with a self-cooked three course dinner and a nice bottle of cava to boot.'

(22) Ook staat er voor iedereen een hapje en een drankje klaar om gezellig samen na te praten.

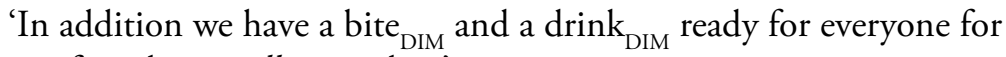
an after-chat gezellig together.'

10 Example (18) agrees with the intuition of an anonymous reviewer who believes that the phrase Hou het gezellig! is 'almost synonymous' with the injunction not to drink too much and that, 'in the historically Protestant influenced Netherlands alcohol is less associated with "gezellig"-ness (a cup of cocoa is "gezellig", a glass of whiskey less likely so)'. 


\title{
3.3. Gezellig + N/Adj referring to bustle or buzz
}

Places can bustle or buzz with people, and that bustle or buzz, too, can be gezellig:

(23) Uiteraard is het altijd een gezellige drukte in onze hout en parket showroom.

'Obviously there is always a gezellig bustle in our wood-and-parquet showroom.'

(24) Op de boulevard langs de haven was het ook gezellig druk.

'On the boulevard along the harbour, too, it was gezellig busy.'

(25) $\mathrm{Na}$ het officiele gedeelte van de receptie ontstond al gauw een gezellige rumoerigheid, die zelfs voortduurde nadat het personeel de bar had gesloten.

'After the official part of the reception there soon arose a gezellig buzz, which lasted even after the staff had closed the bar.'

Explication $[\mathrm{C}]$ accounts for the use of gezellig with a noun meaning 'bustle' or 'buzz':

\section{[C] er heerst hier een gezellige drukte 'there reigns a gezellig bustle here'}

\author{
a. it is like this: \\ b. there are many people in this place \\ c. these people want to be in this place \\ d. they feel something good when they are in this place \\ e. they are doing some things when they are in this place \\ f. they want to do these things for some time
}

There appears to be much less of a difference between explications [B] (gezellige sfeer) and [C] (gezellige drukte) than one might expect. Unlike the former, the latter relies on the prime $\mathrm{MUCH} \sim \mathrm{MANY}$, but only in component (b), which refers to a large human presence. The prime is not needed in the explication of gezellige sfeer, which does not necessarily presuppose large numbers of people, as shown in example (13). On the other hand, there is potential for more diverse activity in a gezellige drukte, 
but this is not a requirement. Different people may be doing different things, with each individual or subgroup contributing to a collective sense of gezelligheid.

\subsection{Gezellig $+\mathrm{N} / \mathbf{V}_{\text {Activity }}$}

Example (26) illustrates the use of the keyword gezellig with the noun activiteit 'activity':

(26) Vrienden of familie die op zoek zijn naar een gezellige activiteit zijn van harte welkom.

'Friends or family who are on the lookout for a gezellig activity are most welcome.'

Activities are usually expressed by means of verbs. Example (27) has a noun and a verb; example (28) has two infinitives:

(27) Dan volgt nog een gezellig samenzijn met muziek van onze eigen DJ Anton en kunt u gezellig meezingen met onze karaoke.

'Then follows a gezellig get-together with music by our own DJ Anton and you can gezellig sing along with our karaoke.'

(28) Turnen is niet alleen goed voor de ontwikkeling, motoriek en kracht van kinderen, maar ook nog eens heel gezellig. Vrienden, vriendinnen, ouders, kom gezellig meedoen, iedereen is welkom!

'Gymnastics is not only good for the development, motor skills and strength of children, it is in addition very gezellig. Friends, parents, join in the fun [lit. come gezellig participate], everyone is welcome!'

Examples (29) to (31) illustrate the very common association between gezelligheid and talking. The latter is often coupled with other activities, as in the latter two examples:

(29) Wil je meer weten, met veel plezier lichten we onze methodiek en wat het voor jullie kan betekenen toe tijdens een gezellige babbel.

'If you want to find out more, we will be delighted to shed further light on our methods and what they can mean for you during a gezellig chat.' 
(30) En toen werd het zo te zien heel gezellig en zaten ze nog een hele tijd met elkaar te drinken, te praten en te lachen.

'And then things apparently got very gezellig and they spent quite some time drinking, talking and laughing together.'

(31) Vandaag hebben we gezellig op een terras in het zonnetje zitten beppen en kleppen, uiteraard ook gedronken en gegeten.

'Today we spent our time gezellig in the sun ${ }_{\text {DIM }}$ at a table in front of a café, chit-chatting; obviously we also had drinks and food.'

Some of our examples oppose solitude or isolation to activities described as gezellig:

(32) Af en toe miste hij het gevoel van een goede vriendschap wel—vooral als hij zijn zus zo gezellig met haar vriendinnen zag rondlopen.

'From time to time he did miss the feeling of good friendshipespecially whenever he saw his sister walk around so gezellig with her friends.'

(33) Waar de rest gezellig bij ons zit in de woonkamer, zit zij 99 per cent van de tijd het liefst beneden in de woonkeuken.

'Whereas the others gezellig sit down with us in the lounge, she prefers spending 99 per cent of the time downstairs in the kitchen.'

The activity envisaged is usually intrinsically social or collective, and entirely voluntary. There is no coercion, no obligation to engage in the activity if people don't want to involve themselves. Explication [D] is an attempt at spelling this out:

\section{[D] een gezellige activiteit 'a gezellig activity'}
a. something people do ${ }^{11}$
b. they want to do it for some time
c. they do it with other people
d. all these people feel something good when they do it

11 The first component of explications [D] and [E] is potentially controversial since it includes a relative clause. The role and place of relative clauses in NSM syntax remains to be further elucidated. 
No reference is made to the place where the activity occurs, since there is nothing to prevent gezellig activities from occurring in ongezellig 'un-gezellig' places. The same is true in the case of events (section 3.5). In terms of gezelligheid, the link between an activity and the place where it occurs is more tenuous than that between a place and its atmosphere (section 3.2) or a place and its bustle (section 3.3).

\subsection{Gezellig $+\mathbf{N}_{\text {Event }}$}

Examples (34) to (36) provide illustration of the use of gezellig with nouns referring to events:

(34) Overal in de Provence vindt u gezellige markten met vaten vol ronde olijven, bergen geurende kruiden en dikke schijven geitenkaas. 'All over Provence you can find gezellig markets with barrels full of round olives, stacks of aromatic herbs and thick slices of goat cheese.'

(35) In het zomerseizoen kunnen we elk (buiten)evenement combineren met een gezellige $\mathbf{B B Q}$.

'In the summer season, we can combine each (outside) event with a gezellig BBQ.'

(36) Al jaren organiseert de bank deze gezellige familiefietsdag voor haar werkgebied.

'For years the bank has been organising this gezellig family cycling day for its work sector.'

Relying on diminutives for increased effect, examples (37) and (38) are to some extent reminiscent of examples (4) to (6):

(37) Thuis heeft zijn vrouw alles in gereedheid gebracht voor een gezellig verjaardagsfeestje.

'At home his wife took care of all the preparations for a gezellig birthday party ${ }_{\text {DIM. }}$ '

(38) Ik ben altijd wel voor een avondje gezellig uit.

'I am always in favour of an evening ${ }_{\text {DIM }}$ gezellig out.' 
The diminutive in (38) favours an event interpretation: the example refers to an outing rather than to a period of time. ${ }^{12}$ The adverb gezellig qualifies the adverb uit 'out'. It would have been equally possible to talk about een gezellig avondje uit, in which case gezellig is an adjective qualifying the noun avondje. The two phrases are very similar in meaning.

Example (39) shows that a gezellig event, like a gezellig activity, can occur in an ongezellig place:

(39) De dag wordt afgesloten met een gezellige maaltijd bij de ongezellige Chinees in de haven en een borrel in de lokale bar. (G) 'The day ends with a gezellig meal at the ongezellig Chinese restaurant in the harbour quarter and a snifter in the local bar.'

Explication [E] is fairly close in its formulation to explication [D], which is of course to be expected since events and activities are related categories:

\section{[E] een gezellig evenement 'a gezellig event'}
a. something that happens
b. it happens for some time
c. it happens when people do something with other people
d. all these people feel something good when they do it

\subsection{Gezellig $+\mathbf{N}_{\text {Period }}$}

Time spent together can be gezellig, too. It is usually relatively short, and filled with collective activity that makes all those present feel good:

(40) Met een volle buik en een kerstpresent werd deze gezellige middag afgesloten.

'We concluded this gezellig midday with a full tummy and a Christmas present.'

(41) $\mathrm{Al}$ met al toch weer een gezellige avond met racen, pinballen en vooral veel gein!

12 The phrase een gezellige avond' a gezellig evening' (no diminutive) favours the latter interpretation. See section 3.6. 
'All in all yet again a gezellig evening with racing and pinball machines and above all lots of fun!'

(42) Jij was bij ons de gezelligste week van het jaar, de kerst.

'You were with us during the most gezellig week of the year, Christmas.'

I propose the NSM explication in [F]:

\section{[F] een gezellige tijd 'a gezellig time'}
a. some time, not a long time
b. at this time, it is like this:
c. people are with other people in the same place for some time
d. they feel something good when they are in the same place with these other people
e. they do some things with these other people

The infinitive phrase er een gezellig(e) $N_{\text {Period }}$ van maken 'make it into a gezellig $\mathrm{N}_{\text {Period }}$ ' is related to the cultural imperative Maak het gezellig! 'Make it gezellig', discussed in section 3.2. It is illustrated in (43):

(43) Alle leden zijn welkom om er weer een gezellige avond van te maken.

'All members are welcome to help make it into a gezellig evening.'

\subsection{Gezellig $+\mathbf{N}_{\text {Hum }}$}

'If someone refers to you as gezellig, take this as a compliment', wrote Kaldenbach (1995), quoted in section 2. To describe someone as gezellig amounts to saying that they are good company, they are fun to be with and at the same time they seek out the company of others. They try hard not to antagonise, but to socialise. Examples of gezellig $+\mathrm{N}_{\mathrm{Hum}}$ in the Sketch Engine sample include the following:

(44) Ik ben een meid van 18 jaar en ga binnenkort bij een bureau werken. Ben tot dan nog op zoek naar gezellige klanten die zin hebben in een leuke, jonge meid. 
'I am an 18-year old lass and will be joining an escort agency shortly. Until then, am looking for gezellig customers who fancy a nice young lass.'

(45) Kinderen worden gelukkiger, gezelliger en beter ontwikkelde mensen als ze de gelegenheid krijgen om met elkaar te spelen.

'Children become happier, more gezellig and better developed individuals if they get the chance to play with one another.'

In NSM, een gezellig iemand can be explicated as in [G]:

\section{[G] een gezellig iemand 'someone gezellig'}
a. someone
b. other people want to be with this someone
c. this someone wants to be with other people
d. when this someone is with other people,

these other people can feel something good because of it

e. this someone doesn't want other people to feel something bad

when this someone does something

g. this is good

[G] is in many ways similar to Waters' (2017: 42) explication of nice as a human attribute (e.g. a nice person). The most important difference lies in components (b) and (c), absent from the explication of nice.

Related to the above is the use of gezellig in the phrases gezellig zijn 'to behave gezellig' and gezellig doen 'to act gezellig', which denote desirable behaviours of people (as opposed to permanent properties). Als je niet gezellig kan doen, ga je maar naar je kamer 'If you can't do gezellig, you might as well go to your room' is, according to van Baalen (2003: 16), an often-heard parental threat to recalcitrant children. Gij zult gezellig zijn 'Thou shalt be gezellig', on the other hand, is according to the same author 'just about the eleventh commandment in Dutch society' (ibid.; my translation). 


\section{Conclusion}

In May 2003, during a visit to Leiden University, Anna Wierzbicka and Cliff Goddard taught a masterclass on 'Empirical universals in semantics: lexicon, grammar, discourse'. Cultural keywords were among the topics addressed, prompting the class to try its hand at explicating a striking specimen of the category, the adjective gezellig. Appendix 3.3 contains English and Dutch versions of the masterclass explication, which didn't relate to the keyword per se, but to an exclamation (Gezellig hier! 'Gezellig here!') featuring the arguably most common use of the word gezellig in today's language: its use as an attribute of a place.

By contrast, the explications in this chapter rely on lexico-grammatical frames of a different nature. Use of gezellig with nouns shows the true versatility of a word that goes equally well with nouns of places, nouns referring to atmosphere, nouns (and adjectives) referring to a bustle or buzz, nouns (and verbs) referring to activities, nouns referring to events, nouns referring to periods, and nouns referring to humans. The list is not complete, but it accounts for the most important and indeed most salient uses of a cultural keyword that has exercised the minds of several scholars yet remains far from having yielded all its secrets.

Exploring gezellig through the prism of NSM, with its fine-grained reductive paraphrases, has led me on a fascinating journey into Dutch linguaculture. I hope to have shed new light on a language-specific concept in a way that makes sense to cultural insiders and outsiders alike. Unlike my predecessors, I have tried to take nothing for granted: neither Dutch linguaculture itself, as is done by those who, like anthropologist Henk Driessen (1997) and theologian Pieter Dronkers (2013), write in their own language (Dutch) for an audience that is obviously aware of what it means to live in and be part of the Dutch linguaculture; nor the cultural baggage that is inevitably embedded (but hardly ever detected) in English scholarly writing, such as that of philosopher Hilde Lindemann (2009), psychologist Alexander McNeil and maternity care specialist Julie Jomeen (2010), or ethnographer Rajendra Pradhan (1990). It should never be forgotten that English is anything but the culture-free medium it is often assumed to be. We can either remain 'imprisoned' in it, to use Wierzbicka's (2014) beautiful metaphor, or take the key that, for years, she has invited us to put to good use. 


\section{References}

Driessen, Henk (1997). Over de grenzen van gezelligheid. In Huub de Jonge (ed.), Ons Soort Mensen: Levensstijlen in Nederland. Nijmegen: Sun, 48-75.

Dronkers, Pieter (2013). Spelbrekers: Hoe gezellig is het nieuwe wij? In Manuela Kalsky (ed.), Alsof Ik Thuis Ben: Samenleven in een Land Vol Verschillen. Almere: Parthenon, 99-114.

Goddard, Cliff (2015). Words as carriers of cultural meaning. In John R. Taylor (ed.), The Oxford Handbook of the Word. Oxford: Oxford University Press, 380-98. doi.org/10.1093/oxfordhb/9780199641604.013.027.

Goddard, Cliff (2017). Natural Semantic Metalanguage and lexicography. In Patrick Hanks and Gilles-Maurice de Schryver (eds), International Handbook of Modern Lexis and Lexicography (online). Berlin: Springer. doi.org/ 10.1007/978-3-642-45369-4_14-1.

Goddard, Cliff and Anna Wierzbicka (1995). Key words, culture and cognition. Philosophica 55 (1): 37-67.

Kaldenbach, Hans (1995). Act Normal! 99 Tips for Dealing with the Dutch. Amsterdam: Prometheus.

Levisen, Carsten (2012). Cultural Semantics and Social Cognition: A Case Study on the Danish Universe of Meaning. Berlin: De Gruyter Mouton. doi.org/ $10.1515 / 9783110294651$.

Levisen, Carsten and Sophia Waters (eds) (2017). Cultural Keywords in Discourse. Amsterdam: John Benjamins.

Lindemann, Hilde (2009). Autonomy, beneficence, and gezelligheid: Lessons in moral theory from the Dutch. The Hastings Center Report 39 (5): 39-45. doi.org/10.1353/hcr.0.0188.

McNeil, Alexander and Julie Jomeen (2010). 'Gezellig': A concept for managing pain during labour and childbirth. British Journal of Midwifery 18 (8): 515-20. doi.org/10.12968/bjom.2010.18.8.49317.

Pradhan, Rajendra (1990). Much ado about food and drinks: Notes towards an ethnography of social exchange in the Netherlands. Etnofoor 3 (2): 48-68.

van Baalen, Christine (2003). Neerlandistiek zonder grenzen: Over het nut van crossculturele taalanalyses. Colloquium Neerlandicum 15, 13-22. 
Waters, Sophia (2017). Nice as a cultural keyword: The semantics behind Australian discourses of sociality. In Carsten Levisen and Sophia Waters (eds), Cultural Keywords in Discourse. Amsterdam: John Benjamins, 25-54.

Wierzbicka, Anna (1992). Defining emotion concepts. Cognitive Science 16 (4): 539-81.

Wierzbicka, Anna (1997). Understanding Cultures through their Key Words: English, Russian, Polish, German, and Japanese. New York: Oxford University Press.

Wierzbicka, Anna (2014). Imprisoned in English: The Hazards of English as a Default Language. New York: Oxford University Press.

\section{Appendix 3.1}

Table A3.1. Dutch exponents of the NSM primes.

\begin{tabular}{|c|c|}
\hline IK, JIJ, IEMAND, IETS DING, MENSEN, LICHAAM & \multirow[t]{2}{*}{ substantives } \\
\hline $\begin{array}{l}\text { I, YOU, SOMEONE, SOMETHING } \sim \text { THING, } \\
\text { PEOPLE, BODY }\end{array}$ & \\
\hline SOORT, DEEL & \multirow{2}{*}{$\begin{array}{r}\text { relational } \\
\text { substantives }\end{array}$} \\
\hline KIND, PART & \\
\hline DIT, HETZELFDE, ANDERE $\sim$ ANDERS & \multirow[t]{2}{*}{ determiners } \\
\hline THIS, THE SAME, OTHER ELSE & \\
\hline ÉÉN, TWEE, SOMMIGE -WAT, ALLE, VEEL, WEINIG & \multirow[t]{2}{*}{ quantifiers } \\
\hline $\begin{array}{l}\text { ONE, TWO, SOME, ALL, MUCH MANY, } \\
\text { LITTLE } \sim \text { FEW }\end{array}$ & \\
\hline GOED, SLECHT & \multirow[t]{2}{*}{ evaluators } \\
\hline GOOD, BAD & \\
\hline GROOT, KLEIN & \multirow[t]{2}{*}{ descriptors } \\
\hline BIG, SMALL & \\
\hline $\begin{array}{l}\text { WETEN, DENKEN, WILLEN, NIET WILLEN, } \\
\text { VOELEN, ZIEN, HOREN }\end{array}$ & \multirow[t]{2}{*}{$\begin{array}{r}\text { mental } \\
\text { predicates }\end{array}$} \\
\hline $\begin{array}{l}\text { KNOW, THINK, WANT, DON'T WANT, FEEL, SEE, } \\
\text { HEAR }\end{array}$ & \\
\hline ZEGGEN, WOORDEN, WAAR & \multirow[t]{2}{*}{ speech } \\
\hline SAY, WORDS, TRUE & \\
\hline DOEN, GEBEUREN, BEWEGEN & \multirow{2}{*}{$\begin{array}{r}\text { actions, events, } \\
\text { movement }\end{array}$} \\
\hline DO, HAPPEN, MOVE & \\
\hline
\end{tabular}




\begin{tabular}{|c|c|}
\hline (ERGENS) ZIJN, ER IS, (IEMAND/IETS) ZIJN & \multirow{2}{*}{$\begin{array}{r}\text { location, } \\
\text { existence, } \\
\text { specification }\end{array}$} \\
\hline $\begin{array}{l}\text { BE (SOMEWHERE), THERE IS, BE (SOMEONE/ } \\
\text { SOMETHING) }\end{array}$ & \\
\hline VAN MIJ (ZIJN) & \multirow[t]{2}{*}{ possession } \\
\hline (IS) MINE & \\
\hline LEVEN, STERVEN & \multirow[t]{2}{*}{ life and death } \\
\hline LIVE, DIE & \\
\hline $\begin{array}{l}\text { WANNEER } \sim \text { MOMENT } \sim \text { KEER, NU, VOOR } \sim \text { ERVOOR, } \\
\text { NA } \sim \text { ERNA, EEN LANGE TIJD, EEN KORTE TIJD, } \\
\text { VOOR EEN TIJDJE, OGENBLIK }\end{array}$ & \multirow[t]{2}{*}{ time } \\
\hline $\begin{array}{l}\text { WHEN - TIME, NOW, BEFORE, AFTER, A LONG } \\
\text { TIME, A SHORT TIME, FOR SOME TIME, MOMENT }\end{array}$ & \\
\hline $\begin{array}{l}\text { WAAR PLAATS, HIER, BOVEN, ONDER, VER, } \\
\text { DICHTBIJ, ZIJDE, IN, AANRAKEN }\end{array}$ & \multirow[t]{2}{*}{ place } \\
\hline $\begin{array}{l}\text { WHERE -PLACE, HERE, ABOVE, BELOW, FAR, NEAR, } \\
\text { SIDE, INSIDE, TOUCH }\end{array}$ & \\
\hline NIET, MISSCHIEN, KUNNEN, OMDAT, ALS & \multirow[t]{2}{*}{ logical concepts } \\
\hline NOT, MAYBE, CAN, BECAUSE, IF & \\
\hline ZEER, MEER & \multirow{2}{*}{$\begin{array}{l}\text { intensifier, } \\
\text { augmentor }\end{array}$} \\
\hline VERY, MORE & \\
\hline ZOALS & \multirow[t]{2}{*}{ similarity } \\
\hline LIKE $\sim$ AS & \\
\hline
\end{tabular}

Notes: Exponents of primes can be polysemous, that is, they can have other, additional meanings.

Exponents of primes may be words, bound morphemes or phrasemes.

They can be formally complex.

They can have language-specific combinatorial variants (allolexes, indicated with ).

Each prime has well-specified syntactic (combinatorial) properties.

Source: Author's summary.

\title{
Appendix 3.2: Dutch versions of the NSM explications proposed in this chapter
}

\section{[A'] een gezellige plaats}

\author{
a. een plaats \\ b. wanneer mensen aan deze plaats denken, voelen ze iets goeds
}



c. ze willen in deze plaats zijn
d. ze willen in deze plaats wat doen ${ }^{13}$
e. wanneer mensen in deze plaats zijn, kunnen ze iets goeds voelen
f. er kunnen in deze plaats met mensen géén slechte dingen gebeuren

\section{[B'] er heerst hier een gezellige sfeer}
a. het is zó: ${ }^{14}$
b. $\quad$ er zijn mensen in deze plaats
c. deze mensen willen in deze plaats zijn
d. $\quad$ ze voelen iets goeds wanneer ze in deze plaats zijn
e. $\quad$ ze doen wat wanneer ze in deze plaats zijn
f. ze willen het voor een tijdje doen

\section{[C'] er heerst hier een gezellige drukte}
a. het is zó:
b. er zijn vele mensen in deze plaats
c. deze mensen willen in deze plaats zijn
d. ze voelen iets goeds wanneer ze in deze plaats zijn
e. $\quad$ ze doen wat wanneer ze in deze plaats zijn
f. ze willen het voor een tijdje doen

\section{[D'] een gezellige activiteit}
a. iets dat mensen doen
b. ze willen het voor een tijdje doen
c. ze doen het met andere mensen
d. al deze mensen voelen iets goeds wanneer ze het doen

13 This very tentative proposal hinges on the realisation of the combination SOMMIGE $\sim$ WAT + IETS $\sim$ DING + DOEN as WAT DOEN, whereas in the English NSM DO + SOME + SOMETHING $\sim$ THING $=$ DO SOME THINGS. Unlike IETS, which is inherently singular, WAT is unmarked for number.

$14 z o$ is a portmanteau for the combination als dit ('like this'), comparable to German so, French ainsi, Italian cosi, Spanish así, etc. 


\section{[E'] een gezellig evenement}
a. iets dat gebeurt
b. het gebeurt voor een tijdje
c. het gebeurt wanneer mensen iets doen met andere mensen
d. al deze mensen voelen iets goeds wanneer ze het doen

\section{[F'] een gezellige tijd}
a. wat tijd, geen lange tijd ${ }^{15}$
b. in deze tijd is het zó:
c. er zijn voor een tijdje mensen in dezelfde plaats met andere mensen
d. $\quad$ ze voelen iets goeds wanneer ze in dezelfde plaats zijn met deze mensen
e. $\quad$ ze doen wat met deze andere mensen

\section{[G'] een gezellig iemand}
a. iemand
b. andere mensen willen bij ${ }^{16}$ dit iemand zijn
c. dit iemand wil bij andere mensen zijn
d. wanneer dit iemand bij andere mensen is,
kunnen deze mensen daarom ${ }^{17}$ iets goeds voelen
e. dit iemand wil niet dat andere mensen iets slechts voelen wanneer dit iemand iets doet
f. dit is goed

15 niet 'not' + een lange tijd 'a long time' = geen lange tijd.

16 A quirk (?) of Dutch NSM syntax: bij 'with' needs to be used here instead of met.

17 'daarom' is a portmanteau matching the English NSM sequence 'because of this'. 


\section{Appendix 3.3: English and Dutch versions of the $\mathbf{2 0 0 3}$ masterclass explication of the adjective gezellig}

The only record of explication [H] I know of ${ }^{18}$ is incomplete: component

(g) is missing. It must have been there, though, since it is part of the Dutch translation [H'] proposed by van Baalen (2003: 21). In line with current NSM practice, components (b) to (h) have been indented to clarify they contribute to spelling out the thought referred to in component (a). Component (d) is indented even further to highlight that it is a subordinate clause depending on component (c).

\section{[H] Gezellig hier! 'gezellig here'}
a. everyone here can think like this:
b. I am here now with some other people
c. these people are all doing some things at the same time
d. because they want to feel something good
e. they don't want anyone here to feel something bad
f. they all feel something good
g. this is good
h. I want to be here with these people

\section{[H'] Gezellig hier!}
a. iedereen hier kan iets denken als dit:
b. ik ben nu hier met andere mensen
c. deze mensen doen allen iets op hetzelfde moment
d. omdat ze iets goeds willen voelen
e. $\quad$ ze willen niet dat iemand hier iets slechts voelt
f. $\quad$ ze voelen allemaal iets goeds
g. dit is goed
h. ik wil hier zijn met deze mensen

18 Available at: waij.com/gezelligheid/primitieven.html. 
This text is taken from Meaning, Life and Culture: In conversation with Anna Wierzbicka, edited by Helen Bromhead and Zhengdao Ye, published 2020 by ANU Press, The Australian National University,

Canberra, Australia.

doi.org/10.22459/MLC.2020.03 